\title{
Psychiatric and Disabled people: Legal and Human Right aspects
}

\author{
Upmesh K. Talwar $^{1 *}$, Ashki Duggal ${ }^{2}$, Ravinder Singh ${ }^{3}$ \\ ${ }^{1}$ Assistant Professor, Dept. of Social Work, Model Public Education College, \\ M.J.P. Rohilkhand University, Bareilly, U.P. -244412, India \\ ${ }^{2}$ Assistant Professor, Department of Social Work, Kurukshetra University, Kurukshetra, Haryana, India \\ ${ }^{3}$ Associate Professor \& Head, Department of Medical Anthropology, Institute of Human Behavior and Allied Sciences, \\ Faculty of Medical Sciences, University of Delhi, Govt. of NCT of Delhi \\ *Corresponding author E-mail: talwarmsw@gmail.com
}

\begin{abstract}
Legislation forms an important component in the implementation of mental healthcare. Legislation is an expression of society with regard to the way it views and cares for mentally ill individuals. It has long been known that there is a dynamic relationship between the concept of mental illness, the treatment of the mentally ill and the existing Law. Mentally ill persons are vulnerable and required protections and access to treatment programmes, significant degree of choice and respect for autonomy. Though there are several laws but these laws are not able to protect the right of the mentally ill person and person with the disabilities. This paper is emphasized on the human rights and legal provisions for mentally and physically challenged people and reviews the existing rights and their importance for the welfare of these groups and also emphasized on their drawback in an Indian Perspective.
\end{abstract}

Keywords: Human Rights, Legal Provisions and Welfare Commas.

\section{Introduction}

Human Rights are the State instruments promising the good life to its people and which are legitimized by the State. It may be categorized as Legal rights and Human rights. Former are such privileges which one enjoys as the citizen recognized by the state. These are legitimized through written legal code and may be classified as Civil and Political. Civil rights are those privileges in the absence of which one cannot enjoy a decent civic life, which are essential for a civilized society. Political rights are recognized and guaranteed by the State. In contrast human rights on the hands are basically the claims of the individual for the fullest realization of the innate characteristics which nature has bestowed him or her with as a human being. In other word, these, right are universal moral right available to everybody irrespective of his or her gender, race, colour, language, national origin age class, religion or creed. Human Rights are those rights which every person is inherent with, just because of his or her human status. No one can take away the human right or ideally not to be taken way because they are the part of human society. Human Rights are inseparable from science and social work theories, values and ethics and practices prevalent in human society. Most of the Fundamental Right is thus falling under the human right which also, includes economic, social and cultural right of an individual. Legislation forms an important component in the implementation of mental healthcare. Legislation is an expression of society with regard to the way it views and cares for mentally ill individuals. It has long been known that there is a dynamic relationship between the concept of mental illness, the treatment of the mentally ill and the Law. In this paper we have illuminated situation of the legislation relating to psychiatric and disabled people and the synoptic view of the prevalent legal safeguards for these marginalized population groups.

\section{Psychiatric care: emergence of human rights as the humanitarian reform}

The possession by the spirits was seen as 'madness' or some form of immorality during middle Age. There were large-scale institutionalizations of those considered lunatics in $16^{\text {th }}$ and $17^{\text {th }}$ centuries. The inmates were treated with cruelty in the early asylums or hospitals. The people of the society had dealt with utter inhuman attitudes. Humanitarian reform of mental hospital and 'moral treatments' of the mentally ill received its first great impetus from work of Psychiatrist Philippe Pinel (1745-1826) in France. He transformed the custodial care system somehow and thought to use the environment of hospital in a benevolent way to cure the patients (Ridgway, 1997). Consequently, in England a layman known as John Tuke also tried to develop healthy and supportive environment in the hospitals. In United States, this humane treatment of mental patients was reflected in the work of Benjamin Rush (1745-1813), the founder of American Psychiatry. Dorothea Dix (1802-1897) energetic schoolteacher in New England followed his early work of reformation. Maxwell Jones (1945) did notable work of transformation of hospital staffs into therapeutic communities to supporting the patients after World War-II.

According to Maurice Cranston, there were three criteria of human rights to ascertain whether a particular right is a human right or not. These criteria are universality, practicality and paramount importance. Cranston established the facts rather than social rights, traditional civil and political liberties meet the three criteria and then subsequent landmark events occurred related to human rights: American Declaration of Independence (1776), French 
Declaration of Rights of Man (1789), The Bolshevik Revolution in Russia (1917), Universal Declaration of Human Rights (1948), European Convention on Human Rights (1950), International Convention of Civil and Political Rights (1966), the 'Helsinki' Accords (1975) etc.

All human beings are born free and equal in dignity and rights (Article-1, Universal Declaration of Human Rights, 1948). Dignity without choice is meaningless and the choice should be ours. But the fact reveals that the choice is not really left to us and same was the case of mentally ill persons. Everyone should be entitled to all rights and freedom without discrimination of any kind. Merely presence of a disease cannot snatch away right of a human being.

\section{Common human rights to Indian people}

The Constitution of India 1956, mentioned the basic Fundamental Right to all Indian Citizens and more consonance to the Human rights. These rights are given in Chapter No III as the Fundamental Human Rights as follows:

Right to Equality (Art. 14-18)

- Art 14- Equality before Law?

- Art 15- Prohibition of discrimination on ground of religion, caste, sex or place or birth?

- Art 16- Equality of opportunity in matter of Public Employment?

- Art 17-Abolition of Un-touchability.

- Art 18- Abolition of titles?

Right to Freedom (Art. 19-22)

- Art 19- Protection of certain rights regarding freedom of speech, etc.

- Art 20- Protection in respect on conviction for offences?

- Art 21- Protection of life and personal liberty?

- Art 21 (A) - Right to Education?

- Art 22- Protection against arrest and detention in certain cases

Right against Exploitation (Art. 23-24)

Right to Freedom of Religion (Art. 25-28)

Cultural \& Education Rights (Art 29-30)

The mentally ill or physically challenged people were accepted as the part of the society and were cared in various temples and religious institution in ancient India. Attempts were made to segregate the mentally ill towards the middle and latter part of the $19^{1 \mathrm{~h}}$ century. They were confined in forsaken stables, barracks and prisons, left to the care of keepers and rods. A British concept Lunatic asylum was established in the colonial India and a landmark Act, Indian Lunacy Act (1912), passed and lunatic asylums were established and lunatic asylums began to be known as 'Mental Hospitals' in the country by end of 1922 .

\section{Improving mental health- emergence of human right to psychiatric patients}

The human rights of Psychiatric patients may be examined in the available light of following development:

1) United Nations Declaration of Human Rights, 1948.

2) International Convention on Civil and Political Rights, 1966

3) International Convention on Economic, Social and Cultural Rights.

4) United Nations Declaration on the Rights of Mentally Retarded Persons, 1971

5) United Nations Declaration on the Rights of Disabled Persons, 1976.

6) United Nations Convention on the Rights of the Child (1989).

7) United Nations' Principles for Protection of Persons with Mental Illness and For the Improvement of Mental Health Care, 1991.

4.1. Fundamental Freedom and basic Rights of Psychiatric Patients
This has been developed fully in the United Nations principles for protection of person with mental illness, 1991 as given below:

Fundamental Freedom and basic rights:

- All persons with a mental illness have the right

- To the best available mental health care,

- To be treated with humanity and respect,

- To protection from economic, sexual and other forms of exploitation, physical or other abuse and degrading treatment.

- Not to be discriminated on the grounds of mental illness.

"Discrimination" means any distinction, exclusion or preference that has the effect of nullifying or impairing equal enjoyment of rights. To exercise all civil, political, economic, social and cultural rights as recognized in the universal declaration of human rights. If a person lacks legal capacity due to mental illness, a person's appointed and any decision shall be made only after a fair hearing impartial tribunal established by domestic law. Where a court or competent tribunal fined that a person with a mental illness is unable to manage his or her own affairs, necessary measures shall be taken, to ensure the protection of his her interest.

4.2. Protection of minors: To protect the rights of minors or Children.

4.3. Life in the community: Every person with a mental illness shall have the right to live and work, to the extent possible, in the community.

4.4. Determination of mental illness (present or future) shall be made in accordance with internationally accepted medical standards. Never be made on the basis of political, economic or social status and Beliefs prevailing in a person's community, and background of past treatment or hospitalization

4.5. Medical examination: No persons are compelled to undergo medical examination to determine whether or not he or she has mental illness except according to a procedure authorized by domestic law.

4.6. Confidentiality: Rights of Confidentiality of information concerning all persons to whom the present principles apply shall be respected.

4.7. Role of community and culture: Every patient shall have the right to be treated and cared for in the community in which he or she lives. They must be treated near his or her relatives or friends when treatment takes place in a mental health facility and to return to the community as soon as possible. He must be given treatment suited to his or her cultural background.

\section{Standards of care}

It is the next aspect of human right. The Standards of care refer to i.) Treatment; ii.) Consent to treatment; iii.) Conditions in mental health and iv.) Resources for mental health

1) Standards of care: Every patient shall have the right to receive health and social care appropriate to his or her health needs. This include no harm, unjustified medication, abuse by other patients, staff or other acts causing mental distress or discomfort.

2) Treatment: Every patient shall have the right to be treated in or with the least restrictive or intrusive environment and treatment appropriate to the patient's health needs and the need to protect the physical safety of others. He must be treated and taken care of based on a individually prescribed plan, discussed with the patient, reviewed regularly, revised as necessary and provided by qualified professional staff. He should be provided mental health care in accordance with applicable standards of ethics for mental health practitioners. Their treatment shall be directed towards preserving and enhancing personal autonomy. 
3) Medication: Medication shall meet the best health needs of the patient. He shall be given to a patient only for therapeutic or diagnostic purposes. He must never be administered as a punishment or for the convenience of others and should be prescribed by a authorized mental health practitioner. They must be recorded in the patient's record.

4) Consent to treatment. Will include informed consent and provide sufficient information on Diagnostic assessment; Purpose, method, likely duration and expected benefit and risk of procedure /treatment; Alternative modes of treatment; and their benefit and risk; Benefit and risk of 'no treatment'. Patient has the right to refuse or stop treatment. Patient shall never be invited or induced to waive the right to informed consent. Physical restrain or involuntary seclusion of a patient shall not be employed unless required to prevent harm o the patient or others. Sterilization shall never be carried out. Psychosurgery and other intrusive and irreversible treatment for mental illness shall never be carried out on an involuntary patient in a mental health facility.

\section{Review procedure for admitted patients}

The need comes from the recognition of the possibility of involuntary admission and the need for safeguards to prevent misuse.

1) Notice of rights: Patient in a mental health facility shall be informed as soon as possible after admission, in a form and a language, which the patient understands of all his or her rights.

2) Rights and conditions in mental health facilities. They stress on full respect of mentally ill person's- a) Recognition as a person before the law; b) privacy; c) freedom of communication; and d) freedom of religion or belief. Similarly there will be adequate a) facilities for recreation; b) facilities for, c) facilities to purchase, d) facilities for entertainment, e) they should not be subjected to forced labour, and f) labour of a patient in a mental health facility shall not be exploited.

3) Recourses for mental health facilities will have access to the same level of resources as any other health establishment, and in particular appropriate professional care, equipment, supplies of medication, etc.

4) Admission and Discharge procedures: Application of proper procedure and the implementation of the admission and discharge procedure of mental patient to hospital can ensure human rights. This also includes process for involuntary admission. Aspects of these are:

i) Admission principles: Where a person needs treatment in a mental health facility, every effort shall be made to avoid involuntary admission and

ii) Involuntary admission will be allowed only if there is a serious likelihood of immediate or imminent harm to that person or to other persons and only for short period

iii) Review body: There shall be a judicial or other independent and impartial body established by domestic law to have a review body which will periodically review the case of involuntary patients

iv) Procedural safeguards:: The patients shall be entitled to choose and appoint a counsel to represent the patient as such including presentation in any complaint procedure or appeal.

v) Access to information: A patient shall be entitled to have access to the information concerning his or her health and personal records maintained by a mental health facility.

vi) vi. Criminal offender: This principle applies to persons serving sentences of imprisonment for Criminal offences, or who are detained in the course of criminal proceedings or investigations against them.

\section{Psychiatric Patients: Indian legal safeguard}

Human right is a neglected issue in most of third world countries and human rights of mentally are the most neglected one. A glar- ing example is the horrific incidence at Erwadi in our country, in which 26 persons with mental illness died in a tragic fire accident on $6^{\text {th }}$ August, 2001. Erwadi, a small village in Tamilnadu, where several mentally ill were chained and shackled in a dargah without any medical treatment. This is an instance of severe violation of human rights which is an eye opener focusing the need for organized mental health care in the country.

The rights of the mentally ill in India have been the subject of public policy and discussion at many levels they are outlined as follows: (Murthy)

- Indian Lunacy Act, 1912. [Replaced by Mental Health Act, (1987) which is at present still under review]

- Integration of Mental Health with Primary Health Care (1975)

- Formulation of National Mental Health Program (1982)

- Improvement of Mental Hospitals (1982)

- Restriction on Admission of Mentally ill to Jail, (1993)

1) Indian Lunacy Act, 1912

The Indian laws related to mental disorders were based on British Acts. For example Indian Lunacy Act (ILA), Act 4 of 1912, was based largely on the earlier English Lunacy Act of 1980 and repealed the existing Indian Lunatic Asylums Act. The ILA had 8 chapters. Chapter 1 defined a lunatic as an Idiot or person of unsound mind. 1n 1950 three eminent psychiatrist appointed by Indian Psychiatric Society prepared a draft "Indian Mental Health Act" and forwarded it to Govt. of India. There was no act taken on the draft for next ten years. It was passed by Rajya Sabha in November 1986. Then it was known as

2) Integration of Mental Health with Primary Health Care (1975)

The most striking aspect of mental health care initiatives is the community based mental health care in last two decade. Such initial efforts were made in Chandigarh and Bangalore (19751981) of mental health care relevant to population units of 1-2 million have been developed as models of mental health care. Bellary District Mental health project requires special mention, as a part of this effort, about manual of Mental Health of different categories of health personnel; simple recording system, training videos, assessment forms and public education materials have been developed.

\section{3) National Mental Health Program (NMHP) of India (1982)}

The change in health policy from a vertical program to programs involving the community resulted in the National Health Policy (1983) with a thrust towards primary health care, decentralization of services and primary, secondary and tertiary prevention initiatives, including rehabilitation. The inadequate care in mental hospitals and the concerns of professional bodies resulted in the adoption of the National Mental Health Policy (NMHP) by the central council of health in 1982. The formulation of NMHP was a milestone in the history of mental health care.

The main objectives of the NMHP are to ensure availability and accessibility of minimum health care for all in the foreseeable, future, particularly to the most vulnerable and unprivileged sections of the population; to encourage application of mental health knowledge in general health care and social development; and to promote community participation in the mental health service development and to stimulate efforts towards self-help in the community. The NMHP envisaged operationalization of the program at least in one district of every stale in the country within a reasonable period of time.

\section{4) Improvement of Mental Hospital, 1982:}

The other important initiative was the judicial intervention to protect the right of the mentally ill person in 1984. These have occurred at different levels of Court of India and the different high courts in Delhi, Ranchi, Poona, and Trivandrum. The standard of Institutional care began to take their shape.

\section{Mental health act (MHA) 1987: revised}

The Parliament of India enacted it to replace the British Indian Lunacy Act-1912. Significant changes were incorporated in this 
act. The term lunatic this was replaced by the term 'Mentally Ill person'. The act provides for the establishing authorities in mental health at the Central and the State level to regulate and oversee the management and treatment of mentally ill.

In 1987, the Mental Health Act was enacted and became law in 1990, and came into force in all states and Union Territories on $1^{\text {st }}$ April, 1993.

There are 10 Chapters and 98 Subsections in the Mental Health Act-1987 as follows:

Chapter-1: Definitions (Sec: 1- 4)

Chapter-2: Mental Health Authorities (Sec: 5- 14)

Chapter-3: Admission and Detention in Psychiatric Hospital \& Nursing home (15-36 totals)

Part -1 : Admission on Voluntary Basis (sec 15-18)

Part-2 : Admission under Special Circumstances (sec 19)

Part -3 : Reception Order-Reception order on Application (sec

20-22)

a) Reception Order on production of mentally ill person before Magistrate (sec 23-25)

b) Further provision regarding admission \& detention of certain Mentally ill (sec 26-29)

c) Miscellaneous provision ( $\sec 30-36)$

Chapter-4: Inspection, Discharge, Leave of Absence \& Removal of Mentally ill (37-49)

Part 1 : Inspection (visitors, mentally ill \& ill prisoners) (sec 37-39)

Part 2 : Discharge (MO, on application, relatives,) (sec 40-44)

Part 3 : Leave of Absence (Grant of leave, leave of absence)

(45-46)

Part 4 : Removal (sec 47-49)

Chapter-5: Judicial Inquisition about- Management of Property (sec 50-77)

Chapter-6: Maintenance cost for mentally ill in psychiatric hospital (sec 78-80)

Chapter-7: Protection of Human Rights of Mentally ill persons (sec 81)

Chapter-8: Penalties \& Procedure (maintenance of Psychiatric Hospital Nursing home, etc) (sec 82-87)

Chapter-9: Miscellaneous (pension, repeal, saving provision of bonds etc.) (Sec 88-98)

In the MHA, 1987 the recognition of human rights is well reflected (Sharma, 1997) in admission and discharge procedure; board of visitors for mental health facilities; research on the concern issues punishment for abuse of rights and licensing of mental health facilities. However some of the following issues are mentioned here as highlights of human rights.

1) Restriction on Jailing of Mentally ill Persons:

The Supreme Court passed a historic judgment on $18^{\text {th }}$ August, 1993 that 'admission of non-criminal mentally ill persons to jails is illegal and unconstitutional'. The mental health professionals had been demanding for the abolition of the practice of admitting mentally ill into the jails for many decades.

2) Mental Illness and Criminal Responsibility:

According to the code of criminal (Cr PC) 1973, the committal proceeding or trial of a person who is incapable of defending himself due to unsound of mind may be in capacitated due to unsoundness of mind in not denied basic human right to a fair trial and arbitrarily deprived of personal liberty. However, critics say this benefit is a double-edged sword. It may ideally aid the trial of the accused, but in reality may indefinitely postponed trial and result in lifelong incarceration in safe custody of mental hospital or jail without right to treatment.

3) Other Social Provisions: There are social provisions related Mental illness and Marriage and Divorce: Under the Hindu Marriage Act, 1995, a marriage with a person who is an idiot or a lunatic at the time of marriage, can be declared as null and void on application.

Judicial separation: If lunacy starts after marriage and continues for two years, even with treatment, the other party can apply for legal separation.
Divorce: Divorce can be decreed if the other party has been incurably of unsound mind for a continuous period of at least three years. But the other party has to pay for the maintenance of the lunatic. In case of Special Marriage Act 1954, it is Applicable to persons from any religion undergoing a civil marriage. Have provisions similar to the Hindu Marriage Act except that a marriage under the Special Marriage Act is valid. Whereas in Muslim Law, a person of unsound mind cannot a marriage and such a marriage if contracted is void. However, if the guardian of the person of unsound mind considers such marriage to be in his interest and in the interest of society and is willing to take up all the monetary obligations of the marriage, then such a marriage, than such a marriage can be performed. To the extent that law either prevents the initiation or contributes to the breakdown of the marriage of a person with mental illness, it hampers normal living (Zawadsky, 1979). Studies have found marital relationship most affected by the stigma of mental illness (Vergehese and Beig, 1974; Prabhu, 1975; Malhotra et al, 1981). Unsoundness of mind is not only a disqualification for marriage as a ground for divorce and judicial separation, but it is also the ground available under all personal law except Christian law. Christian law does not permit this ground given the Sacramental nature of a Christian marriage wherein the spouses are intended to live together in health and sickness.

Suicide and law: India is probably the only country in the world to punish its citizen who attempts to commit suicide under section 309 of Indian Penal Code. The punishment (imprisonment for 1 year or with fine or both) though mild, but the stigma attached to a person having been prosecuted and convicted for an offence is too serious. As per the law, it tries to prevent a person taking his own life by punishing him as such act should not be allowed since life itself is precious to the community.

Property Rights of Persons with Psychiatric Disorder: Persons of unsound mind cannot acquire property through executor contracts but through executed contracts, beneficiary of a gift of a property. Such a person can be a legatee under a will, though neither probate nor letters of administration can be obtained by his/ her. Under the Transfer of Property Act, 1882 (Section-7) only persons competent to contract are authorized to transfer property. A mentally ill person is divested from the right to manage his property only subsequent to a judicial inquisition determining unsoundness of mind and the consequent incapacity. The dichotomy of ownership and management can be resolved by putting the property in a trust with the permission of civil court.

Political Rights of Psychiatric Patients: The Indian constitution does not permit a person with mental illness to exercise his or her role to political right to vote and right to stand for election (The Representation of People Act (RPA) 1950 and 1951).

\section{The disability act and $U$ N convention on right for the disabled persons}

Persons with disabilities are entitled to exercise their civil, political, social, economic and cultural rights on an equal basis with others. Disability "summarizes a great number of different functional limitations occurring in any population in any country of the world. People may be disabled by physical, intellectual or sensory impairment, medical conditions or mental illness. Such impairments, conditions or illnesses may be permanent or transitory in nature." (Standard Rules on the Equalization of Opportunities for Persons with Disabilities). Different expressions are used when referring to persons with disabilities. For example, the term "differently-abled persons" indicates that disability is not perceived as a deviation from the norm. The term "disabled persons" might be misinterpreted to imply that the ability of the individual to function as a person has been disabled. This guide uses the term "persons with disabilities", which is consistent with the language used by the United Nations (UN).

India has recently ratified United Nations Convention in the Rights of the Disabled Persons (UNCRPD). Therefore it has in- 
troduced the concept of legal capacity which has been subject to huge debates and Article- 12 of the Convention talks about "Equality before law. This article deals with the following.

The term "disabled person" means any person unable to ensure by himself or herself, wholly or partly, the necessities of a normal individual and/or social life, as a result of deficiency, either congenital or not, in his or her physical or mental capabilities. Disabled persons shall enjoy all the rights set forth in this Declaration. These rights shall be granted to all disabled persons without any exception whatsoever and without distinction or discrimination on the basis of race, colour, sex, language, religion, political or other opinions, national or social origin, state of wealth, birth or any other situation applying either to the disabled person himself or herself or to his or her family.

Disabled persons have the inherent right to respect for their human dignity. Disabled persons, whatever the origin, nature and seriousness of their handicaps and disabilities, have the same fundamental rights as their fellow-citizens of the same age, which implies first and foremost the right to enjoy a decent life, as normal and full as possible.

i) Disabled persons have the same civil and political rights as other human beings; paragraph 7 of the Declaration on the Rights of Mentally Retarded Persons applies to any possible limitation or suppression of those rights for mentally disabled persons.

ii) Disabled persons are entitled to the measures designed to enable them to become as self-reliant as possible.

iii) Disabled persons have the right to medical, psychological and functional treatment, including prosthetic and orthoticappliances, to medical and social rehabilitation, education, vocational training and rehabilitation, aid, counseling, placement services and other services which will enable them to develop their capabilities and skills to the maximum and will hasten the processes of their social integration or reintegration.

iv) Disabled persons have the right to economic and social security and to a decent level of living. They have the right, according to their capabilities, to secure and retain employment or to engage in a useful, productive and remunerative occupation and to join trade unions.

v) Disabled persons are entitled to have their special needs taken into consideration at all stages of economic and social planning.

vi) Disabled persons have the right to live with their families or with foster parents and to participate in all social, creative or recreational activities. No disabled person shall be subjected, as far as his or her residence is concerned, to differential treatment other than that required by his or her condition or by the improvement which he or she may derive there from. If the stay of a disabled person in a specialized establishment is indispensable, the environment and living conditions therein shall be as close as possible to those of the normal life of a person of his or her age.

vii) Disabled persons shall be protected against all exploitation, all regulations and all treatment of a discriminatory, abusive or degrading nature.

viii) Disabled persons shall be able to avail themselves of qualified legal aid when such aid proves indispensable for the protection of their persons and property. If judicial proceedings are instituted against them, the legal procedure applied shall take their physical and mental condition fully into account.

ix) Organizations of disabled persons may be usefully consulted in all matters regarding the rights of disabled persons.

$\mathrm{x}$ ) Disabled persons, their families and communities shall be fully informed, by all appropriate means, of the rights contained in this Declaration.

Declaration on the Rights of Disabled Persons [G.A. res. 3447 (XXX), 30 U.N. GAOR Supp. (No. 34) at 88, U.N. Doc. A/10034 (1975)].
The Person with Disability Act (PwD Act-1995): It is called as "The persons with disabilities (equal opportunities, protection of rights and full participation) Act 1995". It is applicable to State Government departments, Boards, Corporations, Panchayats, other establishments of State Government and other allied establishments. The Act was passed with a view to undertake various measures for the welfare of disabled people, such as creation of barrier free environments, remove discrimination in the employment, provision of services for early detection and rehabilitation of the disabled. The Act also envisages the establishment of homes for the severely disabled. A disabled person is one whose disability has been assessed at $40 \%$ of any disability by the medical authority. Significantly mental illness has been included as a disability. Mental illness has been defined as any mental disorder other than mental retardation. The Indian Psychiatric Society has formulated guidelines for assessing disability in patients with mental illness called as IDEAS.

Statement of objects and reasons- PWD Act 1995

- Prevention of Disabilities.

- Protection of rights.

- Provision of medical care.

- Education, training, employment \& rehabilitation.

- Create barrier free environment.

- Remove any discrimination.

- Counteract abuse \& exploitation.

- Integration of person with disability in to social mainstream. Persons with Disabilities (Equal opportunities, Protection of Rights \& Full Participation) Act 1995: Chapters are as under:

1) Preliminary

2) Central coordination committee

3) State Co Ordination Committee

4) Prevention \& early detection of disabilities

5) Education

6) Employment

7) Affirmative action

8) Non-discrimination

9) Research \& Manpower development

10) Recognition of Institutions for persons with disabilities

11) Institution for persons with severe disabilities.

12) The Chief Commissioner and commissioners for persons with disabilities.

13) Social security

14) Miscellaneous.

Disabilities $(S-2 i)$ : Classification of Disabilities under the Act: Blindness; Low vision, Leprosy, Hearing, Loco-motor disability, Mental retardation and Mental illness. Mental illness (S 2q) means any mental disorder other than mental retardation. Mental retardation (S 2r) means a condition of arrested or incomplete development of mind of a person which is specially characterized by sub normality of intelligence' and Person with disability (S 2t) means a person suffering from not less than forty percent of any disability as certified by a medical authority'.

Similarly Mental illness (proposed definition) means disorders of the mind that results in partial or complete disturbance in person's thinking, feeling and behavior which often results in recurrent or persistent inability or reduced ability to carry out activities of daily living, self-care, education, employment and participation in social life

Disability (proposed definition) means a physical or mental impairment which has a substantial and long term adverse effect on the ability of a person to carry out normal day to day activities.

Central and State coordination/executive committees:

- Review and coordinate activities of all departments, govt. and non govt. agencies.

- Develop national policies.

- Advise the government.

- Take the cause of persons with disabilities.

Persons with Disabilities (Equal opportunities, Protection of Rights \& Full Participation) Rules- 2006 
Ministry of Social Justice and Empowerment Notification (Gazette No. 49) $18^{\text {th }}$ Feb2002

- Mental illness has been recognized as one of the disabilities (2i).

- Defined as any mental disorders other than mental retardation.

- A committee was constituted to prescribe guidelines for evaluation and assessment of mental illness (6th Aug 2001).

- Authorities to give certificate will be medical board constituted by Govt. (section (1) and (2) of section 73 of Person with Disability act 1995).

- Certificate valid for 5 years or permanent.

- Director General of Health Services (DGHS) will be the final authority.

Authority to give Disability Certificate (Rule 4)

- Medical Board duly constituted by government.

- Members include

Medical Superintendent/Principal/ Head of institution or his nominee - Chairman

Psychiatrist: Member

Physician: Member

At least two of the members including the chair persons of the board must be present $\&$ sign the disability certificate.

Benefits of Disability Certificates

- Travel concession.

- Monthly maintenance allowance.

- Benefits under various programs like Adhara, Ashraya, Rojgaryojanas.

- Income tax benefits.

- Family pension.

- Employment reservation.

- Encouragement of students/self-employment.

\section{The National Trust For Welfare Of Persons With Autism, Cerebral Palsy, Mental Retardation and Multiple Disabilities Act, 1999}

\section{The National Trust:}

The rights of education, employment, to access to housing can be enjoyed by people certain kinds of disabilities? Can a person with mental retardation enjoy the same right to, say, education? Some disabilities have their own needs and require protection and care. The National Trust Act is an attempt in that direction. The passing of this bill is a major step forward for providing rehabilitation in the new millennium. The Trust will seek to strengthen families and also to protect the interests of persons with above disabilities after the death of their parents. The trust will be empowered to receive grants, donations, benefits and transfers. The National Trust $^{1}$ is a statutory body under the ministry of social justice and empowerment, Govt. of India set up under the 'National Trust future for the welfare of persons with autism, Mental Retardation and multiple disabilities Act. (Act 44, 1999).

Objectives of National Trust:

- To enable and empower persons with disability to live independently and as full as possible with in and as close to the community to which they belong.

- To strengthen facilities to provide support to persons with disability to live within their own families.

- To extend support to registered organizations to provide need based services during the period of crisis in the family of persons with disability.

- To deal with problems of persons with disability who do not have family support.

- To promote measures for the care and protection of persons with disability in the event of death of their parent or guardian.

- To evolve procedures for the appointment of guardians and trustees for persons with disability requiring such protection.
- To facilitate the realization of equal opportunities, protection of rights and full participation of person with disability.

\section{Discussion}

Chapter No 1: Some Drawback of Mental Health Act 1987 , (MHA, 1987)

- Exclusion on Mental Retardation: In the Mental Health Act 1987 by its present definition of "mental patient" has put an explicit bar on the treatment of mentally retarded persons, including the profoundly retarded, in psychiatric hospitals. Existing institutions of retarded are unable to take care of them, patients of profound retardation have no place to seek professional help and assistance, even in their state of utter helplessness (Antony, 2002). Exclusion of mental retardation from the scope of the Act is viewed as if these are fundamentally different condition to mental illness (Akhtar and Verma,1990)

1) Definition of Psychiatrist (MD/DPM)

- Psychiatrist includes a medical officer who has been declared as a psychiatrist by reason of his knowledge and experience by the state. The MHA stipulates that every hospital or nursing home should have a psychiatrist (MD or DPM) as In-charge, but this is a loop whole provision which enables the government to designate any doctor as psychiatrist for the purpose of this act (Kala, 1997, Dhanda et. al, 2004). This provision may be misused by the person in getting license for establishing the psychiatric' hospital or nursing home (Akhtar and Verma, 1990).

2) Definition of Medical Practitioner

- Medical as Homeopathic, Ayurvedic and other non-MBBS doctors have also been empowered to certify admissions. It seems highly contradictory since death certificates, medical and fitness certificate by these practitioner are invalid for insurance and other related purpose. (Channabasavanna, 1985).

3) Inclusion of Nursing Home:

- UN Commission on Human Right recommended that, Mental Institutional should not cover the term "Nursing Center". These salutary guidelines do not appear to have carried any weight with the sponsors of MHA1987. (Antony, 2000)

Chapter No-2

1) No provision of budget.

- There is no mention of a budgetary provision for the Mental Health Authority (Gautam, 1997) Government of India should create a funding body- something like a mental hospital grants commission, to make available funds for upgrading mental hospital as per the direction of respective state mental Authorities (Antony2000).

2) Chairmanship of Mental Health Authorities.

- All Mental Health Authorities, without exception, are chaired by non- psychiatrists and there have been Mental Health Authorities without even one psychiatrist. Pity is that the concerned secretary (health) who is the ex-officio chairman of most mental health authorities has so little time for it that there are mental health authorities which have not had a single meeting in 3 years of existence. (Kala1997)

Chapter No-3

1) Licensing the practice of psychiatry.

- According to section 6 , it is mandatory to obtain a license to maintain or establishing a psychiatric hospital or nursing home (including De-addiction centers). When specialist of other medical or surgical discipline are required to go through such legal orders, why only psychiatrists?

Chapter No-5

1) Provision of Visitors

- To retain the provision of "visitors" for inspection and examining the patient in the modern contest is unwarranted and obsolete. It denies the right of a mentally ill person to secure treatment privately or in any psychiatric hospital of his choice unlike any other patient suffering from physical illness. (Gopalakrishnan, 1990) 
- Provision of seeing a mentally ill prisoners every 3 months by a psychiatrist, is too merge a treatment that can be provided to patient in prison (Akhtar, Verma,1990)

1) Denial of leave of absence to voluntary patient:

- Leave of absence up-to 60 days is available to mentally ill patient detained in a psychiatric hospital, but the voluntary patient is for denied leave. (Gopalakrishnan,1990)

Chapter No-8 Protection of Human Rights of Mentally Ill Persons

Sec-2: No mentally ill persons under treatment shall be used for the purpose of research, unless. Such research is of direct benefit to him for purpose of diagnosis or treatment. (Antony, 2000)

Chapter No-9

- These deals with human rights of the mentally ill. Cruelty has not been defined. A provision for punishment to persons treating mentally ill with such cruel procedures (like branding, physical, punishment) should be made, which does not exist in the law (Gautam, 1997)

\section{Political Rights of Psychiatric Patients:}

The Indian constitution does not permit a person with mental illness to exercise his or her role to political right to vote and right to stand for election (The Representation of People Act (RPA) 1950 and 1951)

The constitution did not clarify such kind of question as what is the:

1) Degree of understanding of judgment required exercising the right to vote?

2) What should be the standard incapacity in quantitative electoral system?

(Thus a person who is able to identify parties and candidates and is able to cast his or her vote can be regarded as possessing capacity to exercise his or her franchised rights Thus this kind of law does not serve any purpose other increasing the negative image and stigma attaching to persons of unsound mind.)

Suicide and law:

Most countries do not consider attempted suicide as an offence. Suicide is an act of distress, indicating that the person requires assistance in his personal and psychological life, not punishment by fine and/or imprisonment. It demands care, sympathy, and treatment

Recommendation of the Indian Psychiatric Society (IPS), 1987:

To rectify the large number of defects, inconsistencies and discriminatory provisions in the Mental Health Act, 1987 the IPS submitted the following to the Govt. of India.

The IPS, the national organization of psychiatrist in India, should be consulted in the matters to mental health policy and mental health legislation by the government.

The Government of India is urged to declare its Mental Health Policy and the plan and program based on the said policy.

The Mental Health Act 1987 should be repealed by new legislation which should base on:

- Mental Health Policy of the Govt.

- Modern concept of psychiatry.

- Basic statutory structure of mental health legislation as laid down in the guiding principles and the alternative approaches recommended by, WHO on 1973

- Principles, guidelines and guarantees for the protection of persons of detained on the ground of mental health or suffering from mental disorder adopted by UN in 1991.

\section{Now Disability:}

Different expressions are used when referring to persons with disabilities. For example, the term "differently-abled persons" indicates that disability is not perceived as a deviation from the norm. The term "disabled persons" might be misinterpreted to imply that the ability of the individual to function as a person has been disabled. This guide uses the term "persons with disabilities", which is consistent with the language used by the United Nations (UN).

Critical Review- Persons with Disabilities (Equal Opportunities, Protection of Rights and Full Participation) Act 1995
Though the act seeks to place the disabled person at par with other sections of the society in respect of jobs, education and vocational training but it suffers from some drawbacks like---

- A person can avail of such benefits only on the basis of medical certificate.

- The act has no provision to punish fraudulent medical professionals.

- Beside this, for mental illness it does not clearly delineate what should be the criteria for the disability or impairment. There is no objective quantification

- This law also does not include the people suffering from $\mathrm{Au}$ tism, Cerebral Palsy and Multiple Disabilities.

Several recommendations were suggested for this act regarding several aspects by the Persons with Disability Act Amendment Committee in their final report published in March 1999. Some of them are

- Inclusion of universal immunization plan as a duty of the appropriate of government

- Guarantee a right to persons with disability to have access to all form of educational programmes.

- Setting up sheltered workshop by the Govt.

- To include a section prohibiting discrimination on grounds of physicals mental or sensory impairments whether or not included in Act.

- Free medical care and treatment to be provided.

- Nutritional residential medical developmental and educational needs of children without cares are the joint and several responsibilities of central and state governments and local authorities.

- Designated institutions should procure benefits from state for persons with severe disability

- Insurance and other social security schemes are recommended.

The concept of IDEAS (Indian Disability Evaluation and Assessment Scale):

As a disadvantage of the Disability Act most policy planners were struck by the lack of comparability of psychiatric disability with other disabilities mainly because here were no guidelines on its measurement. Although a few tools are available for this purpose, they did not seem quite appropriate for the purpose of certifying disability and quantifying it.

The Development of the Indian Disability Evaluation and Assessment Scale (IDEAS) signified a major milestone in the care and rehabilitation of mentally ill persons in this country. This scale is developed by the rehabilitation committee of Indian Psychiatric Society. Dr. R Thara and Dr. T. Murli are the main persons who contribute much in this project. The Scale mainly measures the extent of disability in the following areas i.e.

i) Self-Care

ii) Interpersonal Activity (Social Relationship)

iii) Communication and Understanding

iv) Work

General guidelines:

- IDEAS is suited best for the purpose of measuring and certifying disability

- It is therefore a brief and a simple instrument, which can be used, even in busy clinical settings.

- Some training is required in the use of IDEAS

- This is to be used only in out patients and those living in the community. Not appropriate for in patients.

- Rating should be done only based on interviews of the primary care givers. Case records and patient interviews can be used to supplement information.

- Only in rare instances when no primary care giver is available, should the rating be based only on patient interview.

- The gender specification 'he' has been used for convenience and refers to both genders.

- Probe question help to guide one through the interview and to help identify dysfunction in one or more activities. (sentence problem) 
Drawback of National Trust Act-1999: The National Trust for welfare of persons with autism, cerebral palsy, mental retardation and multiple disabilities Act- 1999(National Trust Act1999).National Trust Act is one of the most important steps to preserve the human right of the persons suffering from the mental retardation, cerebral palsy and multiple disabilities. But this law also has some limitations as: i. the census on disability conducted in 1981 did not give a correct estimate of disabled in our country; ii. RCI Act has a clause says that tile members of the organization will be sent to jail if they are working with disabled without getting registered. The law should be reformed; iii. Here is lack of awareness about the act amongst the parents and guardians of the disabled; IV. Government has not taken steps to popularize the act. Furthermore, it has not been into various regional languages, which is another hurdle in creating awareness; v. There is no defined provision for the floating population like for people in armed forces; VI. The parents have to show a disability certificate for which they have to show birth certificate. But many children are born at home and they do not have the birth certificate.

\section{Concluding \& some of the important Issues}

We make an end note about two crucial issues viz: Human Rights in Psychotherapy \& Testing Ethical responsibility. Every professional who is a practitioner and who is putting into practice the skills and techniques for the welfare and good of the clients is expected to follow certain principles, rules, regulations and procedures so that neither the client nor the therapist get exploited or taken advantage of in process of helping. In 1953 the Ethical standards of psychologists (APA, 1953) was formally published and later modified in 1981 (APA, 1981). This was subsequently amended in 1990 (APA, 1990) and covered ten areas such as

1) Responsibility

2) Competence

3) Moral and legal standards

4) Public statements

5) Confidentiality

6) Welfare of the consumer

7) Professional Relationship

8) Assessment Techniques

9) Research with human participants and

10) Care and cure of animals/ human being (Pharas, 1992).

Ethical responsibility: There are some ethical issues related to psychological testing and treatment which directly resonate with the aspects human right. These are Intelligence Quotient (IQ) and Psychiatric Treatment.

Intelligence Quotient (IQ) testing is done by a large number of psychologists. It is ending up in a type of labeling an individual. It harms the person concerned in two important ways. One, it brings down the self-esteem of the individual and makes the family members of the subject to use it is an explanation to many of the subject's behaviors which could otherwise be improved upon. Other, it is also the ethical responsibility of the professional psychologist to investigate a problem and to be convinced that a particular test is essential or needed to provide additional information for rendering better service to the client. Human right aspect demands that the privacy of the individual subject in regard to sharing or revealing of his test results should be upheld and without the subjects permission the test results should never be given to anyone. Confidentiality is the central principle that binds the client and the therapist into a relationship which pivots them through the various the therapeutic sessions. The rule of confidentiality only is violated in those cases where the information is provided by a client indicating that the patient may be dangerous. There are also many areas such as child abuse, potential suicides and homicides which cannot be kept confidential. Unsupervised intervention and such research studies by student or trainees is another issue where human right is often violated (Ruban O Witz, 1987). There are ethical problems in such studies where one group gets the benefits while the other does not. In cases where one patient group suffering from a certain disorder receives trials with psychotherapy or drug and another group being deprived of the treatment until the treatment is proven to be useful, incidentally also raises the discrimination aspect of ethical issues (Imber et al, 1986; Heflinger, 1987). The issues of ethics act stands will weigh heavily in any professional area that allows for so many role conflicts biases distortion and objectively (Arcaya, 1987, Cornell 1987). The profession of psychology was changed considerably so the goal that binds all psychologists working in different areas specialization is to apply their knowledge skills to needs of the people in their particular discipline.

In case of psychiatric treatment, there is an increasing concern about the abuse of psychiatry or psychiatric malpractice in recent years. The World Psychiatric Association's Hawai Declaration, 1983 describes in the article no. 7 that the psychiatrist must never use his professional possibilities to violate the dignity of human rights of any individual or group and should never let inappropriate personal belief interfere with the treatment and never utilize the tools of his profession once the absence of psychiatric illness has been established. There are some areas where human rights of the patients are violated: exploitation - which may be physical, emotional or sexual; standard of care (includes misdiagnosis of illness and negligence) and drug treatment (includes wrong medicine, over dose etc). As per report of National Human Right Commission of India, there are instances of violations of Human Rights of Mentally and Physically Challenged people in different countries as well as in India. A better infrastructure of awareness and education regarding human right of those working with mentally and Physically Challenged people, strict supervision by the govt. and increase in the mental health professional would definitively improve their situation. There is some hope of reaching close to the realistic goal of protection of their rights in this country.

\section{Acknowledgment}

This paper was presented in the International Conference of Sociology of Law, Organised by International Sociological Association in association with CUHP during 10-12 September, 2011. We are thankful the comments given by the participants of the Conference and of the comments of IJH experts reviewer on this paper.

\section{Notes}

(1) The National Trust is an organization for the Welfare of persons with Autism, Cerebral Palsy, and Mental Retardation \& Multiple Disabilities under the Ministry of Social Justice \& Empowerment, Govt. of India. It can be approached at $9^{\text {th }}$ Floor, Jeevan Prakash Building, K.G. Marg, New Delhi-110001.Email: nationaltrust@nic.in, Website: nationaltrust.org.in,

\section{References}

[1] Agrawal, A. K. and Gupta, S.C. (1999) Ethics in Psychiatry. In: Textbook of Postgraduate Psychiatry, Edn 2, Vol 2, (Eds) Vyas, J.N. \&Ahuja, N. pp1010-1024 New Delhi, B1 Churchill Livingstone.

[2] Akhtar, S. Khess, C.R.J. \& Sinha V.K. (1998) Human Rights of the Mentally III: The Scenario In India, Journal Of Eastern Zonal Branch, 2(1) 20-23.

[3] Alem, J.L. (2000) Human Rights and Psychiatric Care in Africa with Particular Reference to the Ethiopian Situation. Acta Psychiatrica Scandinavia, 101, 399, 93-96. http://dx.doi.org/10.1111/j.09024441.2000.007s020[dash]21.x.

[4] Andreopoulos, J.G. (2000). Declaration and Covenants of Human Rights and International Codes of Research Ethics. Biomedical Research Ethics: Updating International Guidelines - A Consultation. (Eds) Levine JR, Gorovitz, S. J. \&Gallagher, J. Geneva, CIOMS. Pp1881-2003

[5] Antony, T.1. (2000). A Decade with the Mental Health Act, 1987, Indian Journal of Psychiatry, 42(4) 347-355

[6] Antony, .J.T. (2002) Let Us Learn the Right Lessons from Erwadi. Indian Journal of Psychiatry, 44(2), 186-192. 
[7] Bakshi, M.P. (1997) Marriage, Divorce and Mental Health, Monograph Series, IHBAS, Delhi, 3035

[8] Bhattacharya, S. (2003). Social Work: an integrated approach, D\&D Publication, Pp109-110

[9] Bienanfield, D. \&Kapp, M. B. (1997) Special Issues in Psychiatric Ethics. In: Psychiatry, Vol 2, (Eds) Tasman, a Kay, J. \&Liberman, J. A, W.B. Saunders Co.

[10]Chadda, K.R. (1997) Confidentiality and informed Consent, Monograph Series, IHBAS, Delhi 73-80.

[11]Chiswick, D (1996) Forensic Psychiatry. In: Companion to Psychiatric Studies, (eds) Kendall \& Zealley, pp783-801, London, Churchill Livingstone.

[12]Dhanda, a (2000). Legal Order and Mental Disorder, New Delhi, Sage Publication.

[13]Gautam,S (1997) Mental Health Act (1987) How helpful? A Critical Evaluation, Law Ethics and Psychiatry, Monograph Series, IHBAS, Delhi, 9-19.

[14]Geller, J.L. (2000) At the Margins of Human Rights and Psychiatric Care in North America, ActaPsychiatrica Scandinavia Supplement, 1 01, 399, 87-92.

[15]Gostin, L. (1985) Human Rights in Mental Health, Psychiatry Human Rights and The Law, Cambridge University press, 138-147.

[16]Halasz, .G (1996) The Rights of the Child in Psychotherapy, American Journal of Psychotherapy, 50(30), 285-297.

[17]Hand book of Information on A Few Issues. National Trust booklet Handbook of National Trust Act

[18]Harding, T.W. (2000) Human Rights Law in the Field of Menta Health: A Critical Review, ActaPsychaitrica Scandinavia Supplementation, 101, 399, 24-30. http://dx.doi.org/10.1111/j.09024441.2000.007s020[dash]6.x.

[19]Helmchen, H \& Okasha, A (2000) From TheHawai Declaration to the Declaration of Madrid, ActaPsychaitrica Scandinavia Supplementation, 1 01, 399, 20-23.

[20]IDEAS (2002). Indian Psychiatric Society.

[21]Kaplan, I. H, \&Sadock, J.B. (1998) Forensic Psychiatry. In: Synopsis of Psychiatry, $8^{\text {th }}$ Edn. Eds Kaplan, I.H. \&Sadock, J.B., USA Wiliams\&Willkins. Pp1305-1320.

[22]Karna, G.N. (1999) the Role of United Nations and Other International Bodies. In: United Nations and the Rights of Disabled Persons: A Study in Indian Perspective, PP 40-43, and New Delhi, APH Publishing Corporation.

[23] Krishnamurthy, K. Venugopal, D. \&Alimchandani, A.K. (2000) Mental hospitals in India, Indian Journal of Psychiatry, 42(2), 125-132.

[24]Kumar, A.K. (1997) Abuse of Psychiatry (Psychiatric Malpractice), Monograph Series, IHBAS Delhi, 60-65.

[25]Lerav, I. \& Uzcategui, Gonzalez. (2000) Rights of Persons with Mental Illness in Central America, ActaPsychaitrica Scandinavia Supplementum. 101, 399, 83-86.

[26]Malhotra, H.K. Jaman, A.S. \&Chera, D.H. (1981) Do The Psychiatric Patients Reject Themselves? Indian Journal of Psychiatry, 23(1), 44 48.

[27]Mondal, N. Bhattacharya, D. Roy, D. \&Verma, AN. (2001) erase the stigma. Souvenir $14^{\text {th }}$ National Conference of Indian Association for Social Psychiatry, Central Institute of Psychiatry, Ranchi, 45-49.

[28]Munjal, G.N. \&Ahuja, N. (1999) Forensic psychiatry. In: Text Book of Post Graduate Psychiatry, Edn 2, Vol 2, (Eds) Vyas, J.N. \&Ahuja, N. pp 998-1018. New Delhi, BI Churchill Livingstone.

[29]Murthy, RS. (2001) Lessons from the Erwadi Tragedy for Mental Health Care in India. Indian Journal of Psychiatry, 43,362-377.

[30]National Human Rights Commission (1999) Quality Assurance In Mental Health. National Human, Rights Commission of India, New Delhi.

[31]Rao, VA (1975). India, In World History of Psychiatry, Bruner/Mazel Publishers, New York 624-649.

[32] Selvaraj, K. \&Kuruvilla, K (2001) In the Aftermath of Erwadi. Indian Journal of Psychiatry.43, 368.

[33] Sharma, S (2000) Human Rights in Psychiatric Care: An Asian Perspective, Acta Psychiatric Scandinavia Supplementum, 101, 39, 97 1000. http://dx.doi.org/10.1111/j.0902-4441.2000.007s020[dash]22.x.

[34]Simon, R I. (1999) Legal Issues in Psychiatry. In Comprehensive Textbook of Psychiatry, Edn $7^{\text {th }}$ Vol.2 (Eds) Kaplon, H.I \&Sadock, B.J. pp 3272-3289, London, Lippincott William \&Wilkins.

[35]Syrse, A \&Nilstun, T (2000): The Right to Accept and Right To Refuse. Acta Psychatrica Scandinavica Supplementum, 101, 399, 31-39 http://dx.doi.org/10.1111/j.0902-4441.2000.007s020[dash]7.x.

[36]Tardiff, K. (2001) Violence,in Text Book of Psychiatry 31-d Edn, Jaypee Brothers Medical Publishers (P) Ltd. 1405-1428.

[37]Teplin LA, Abraham K.M. \& McClelland G.M. (1996): Prevalence of Psychiatric Disorders among Incarcerated Women Pretrial Jail De- tainees, Archives of General Psychiatry, 53(6), 505-512. http://dx.doi.org/10.1001/archpsyc.1996.01830060047007.

[38]The Mental Health Act (1987) Lucknow, Eastern Book Company

[39]Trivedi, J.K. (2001) Implication of Erwadi Tragedy of Mental Health Care System in India. India Indian Journal of Psychiatry. 43,293-294.

[40]Trivedi, K.J. (1997) Law and Suicide. Law Ethics and Psychiatry, Monograph Series, IHBAS Delhi, 23-29.

[41]Trivedi, K.J. (1999) Disability Benefits For Psychiatrically III, Indian Journal of Psychiatry 41 (3), 177-178.

[42]Trivedi, K.J. (2002) The Mental Health Legislation: An Ongoing Debate, Indian Journal of Psychiatry 44(2), 93-96

[43]Veeraraghavan, V. (1997) Ethical Issues In Psychological Practice And Research, Monograph' Series. IHBAS, Delhi, 93-104.

[44]Wetstein, RM. (1999) The Right To Refuse Psychiatric Treatment. The Psychiatric Clinics of North America, 22(1). http://dx.doi.org/10.1016/S0193-953X(05)70067-8.

[45]World Health report (2001): Mental Health: New Understanding New Hope. Geneva. 